ployers of TSTI graduates. The library solicits the information from each program and tries to update it each year by contacting the various programs for the information. It is helpful in letting students see where former graduates of their technology program are now working. The list varies in quality and is mainly dependent on the effort of each program to supply the information to us. Of course, the student can also gain this information from his or her program, but it has proved convenient to have this compilation at the library also.

Overall, I think the presentation to the Laser Club went very well. I could tell they were grateful someone took the time to talk to them because so many of them asked questions and commented on how they really appreciated my time. I'm looking forward to giving this type of presentation more often. Students or faculty do not usually request such a service, but it is obviously needed. The success and extent of this service rests with the librarian. I feel it is worthwhile because after all, when we give library instruction classes one of our goals is for the student to view the library as an information place-not just a study hall during their years of college, but as a resource place anytime, now and in the future. And what better way to solidify this concept than helping them pursue a career? Lifelong learning exemplified!

\title{
Science collections in
}

\section{community college libraries}

\author{
By Kate Bradley \\ Acquisitions Librarian \\ Bellevue Community College, Washington
}

\section{Using the conspectus to assess curriculum support.}

\begin{abstract}
A s a community college library in the Pacific Northwest we had an opportunity to participate in the Library and Information Resources for the Northwest (LIRN) regional assessment project. Because of staff turnover at the time, Bellevue Community College did not become involved in the initial stages of LIRN. Early reports from other community college libraries performing the LIRN assessment did not encourage belated participation.

For community colleges the main advantage of doing the assessment was that librarians gained hands-on familiarity with their collections, becoming aware in many instances that major portions of
\end{abstract}

the library were badly outdated, requiring extensive weeding and replacement. The deficiency of the LIRN project has to do with the nature of community colleges in Washington state and the relationship of the libraries to the colleges.

As education costs rise and acceptance into the state universities becomes increasingly competitive, the function of community colleges has gradually shifted from two-year vocational/technical training to undergraduate preparation for transfer to four-year institutions. In the spring of 1988 , “among bachelor's degree recipients at public regional institutions, about $48 \%$ were students who transferred credits from a Washington community 
college."l While many individual, institutionally complete programs still do exist at the community colleges, the colleges increasingly resemble each other in offering undergraduate requirement courses in sciences, humanities, social sciences and business. $^{2}$

Since the mission of the community college libraries is to support the curriculum, logically the collections will resemble each other in providing concentrations of materials which LIRN rates " $2 \mathrm{~A}$, Basic Level" and " $3 \mathrm{~A}$, Basic Study" in the basic subject areas. Specialized programs, such as ultrasound technology at Bellevue Community College, mean that ultrasound technology books and journals are located at BCC, but these materials are in high demand at the college and will not be readily available for interlibrary lending.

Also, since community colleges share the same state funds, they have relatively the same problems in budgetary constraints for developing collections. Some libraries have an annual book budget of only $\$ 8,000$ for new titles, which is not adequate for even minimal maintenance, much less "development" or resource sharing. More fortunate libraries, with an annual book budget of $\$ 25,000$ or more, may have areas of strength relative to the poorer libraries, but these areas of concentration are generally reflecting curriculum demands and are not likely to be sought out by other colleges or public libraries. In addition, the higher budget figures may reflect only intermittent efforts to redress neglect, in which case the monies are used to fill long-standing gaps rather than to build recognizably strong collections in particular subjects.

Furthermore, the faculty at community colleges have teaching as their primary or sole function. They are not, generally, engaged in research, and do not have graduate students working on specialized projects, so that no marked depth in any particular subject is likely to be generated by faculty requests.

Thus, the focus of the LIRN project on cooperative collection development and resource sharing does not, overall, address the realities, problems and needs of community college library users.

Nevertheless, the conspectus methodology did, with modifications, prove useful in evaluating, weeding, and updating the science collection of the BCC library. Rather than using the LC classification schedule to describe strengths and weaknesses

\footnotetext{
${ }^{\mathrm{l}}$ Washington State Board for Community College Education, A Study of the Role of Community Colleges in the Achievement of the Bachelor's Degree in Washington State (Olympia: The Board, January 1989), 2.

${ }^{2}$ See Larry R. Oberg, "Evaluating the Conspectus Approach for Smaller Library Collections," College \& Research Libraries 49 (1988): 187-96; and Stewart Saunders, Harriet Nelson, and Priscilla Geahigan, "Alternatives to the Shelflist Measure for Determining the Size of a Subject Collection," Library Research 3 (1981): 383-91.
}

relative to other libraries, the schedule was used to assess adequacy of the collection in meeting its described purpose of curriculum support.

Using syllabi provided by science instructors and course descriptions from the college catalog, I listed classification numbers for what the library ought to have in its science collection. This "cataloging the curriculum" was most direct in physics: the course description of a series of General Physics classes "includes units, kinematics, vectors, dynamics, work and energy, momentum, rotational motion and harmonic motion; heat, temperature, thermodynamics, electricity and magnetism; wave motions, sound, light, geometric and physical optics, relativity, and modern physics."

Classification numbers for these topics, in shelf list order, are, in part:

QA841-QA845 Motion

QA846 Dynamics

QA867 Harmonic Motion

QC73 Work and Power

QC225 Sound; Acoustics

QC311-QC320 Heat Transfer and Thermodynamics

QC353-QC358 Light

QC355 Optics

QC448 Fiber Optics

QC517-QC523 Electric Fields

QC751 Magnetism

My reasoning was that faculty or students requiring more information than that provided by the class text on, for example, thermodynamics, could obtain that information from another current physics textbook title owned by the library (QC21) or from a book on thermodynamics (QC311-QC320). If the library lacked current books in either area, the gap should be filled.

After compiling the classification numbers whose presence on our shelves would indicate curriculum support, I arranged them in correct schedule order. I then compared this list to the current published LC classification schedules and supplemented the list with the numbers for topics such as lasers, holographs and superconductivity, which were not described in either course descriptions or syllabi, but which should be covered by any up-todate science collection.

The project was taking place during the summer months, which meant that the majority of library books were present on the shelves. As a first step, however, I tabulated under each classification number the books, and their copyright dates, which were checked out. Having completed this step, I began reading shelves. I chose this method rather than using shelflist cards because I wanted to record the frequency with which individual titles were checked out to identify areas of heavy use or lack of use.

Notations from the Physics subject area read, for example:

QA433 Vectors-" no books specifically, but 


\section{Staying up-to-the-minute with the fast-breaking research}

that is shaping our future has never been easier with...

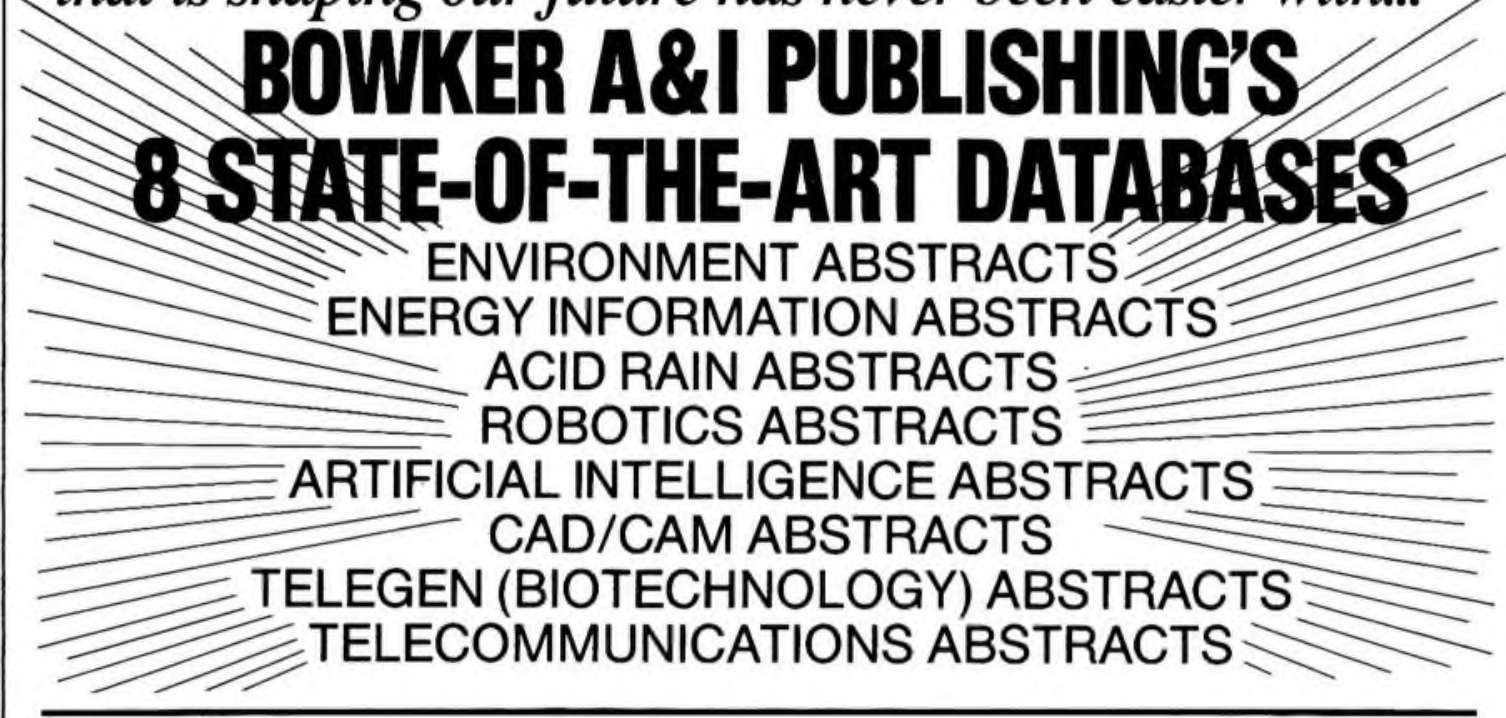

...because every month Bowker's eight carefully compiled journals abstract and index thousands of articles on environmental studies, energy, acid rain*, robotics, artificial intelligence, $C A D / C A M$, biotechnology, and telecommunications. The information found in each publication is drawn from over 1,700 international scientific, economic, technical, academic, and trade journals plus scores of leading general-circulation newspapers, magazines, and wire services.

\section{More than just journals.}

Better still, our journals are part of a sophisticated document retrieval system that lets you order comprehensive microfiche collections carrying the full text of over $80 \%$ of the articles we cite. And you can order microfiche or paper copies of individual articles on a per-document basis as well. In addition, all eight databases are available online from the top online services.

What's more, Bowker A \& I Publishing's journals bring together the "grey" or elusive literature -- conference proceedings, government studies, scientific association reports, even patents -- that often is neither indexed or available in any readily accessible medium.

So whether you're looking for the latest findings on gene products, ozone depletion, nonconventional fuels, U.S. acid rain policy, robot locomotion, human-machine interfaces, or any of hundreds of other crucial high-tech issues, don't bury yourself in indexes or burden yourself with serials orders.

*Acid rain is abstracted and indexed every two months.

\section{Look to Bowker A \& I Publishing to keep you current with the literature. You'll not only make a small research breakthrough yourself...you'll make a big one easier for your patrons, too.}

\section{Call Now For a Free Sample Journal!}

TO ORDER -- OR FOR MORE INFORMATION ABOUT OUR INTEGRATED SYSTEM OF MONTHLY JOURNALS, ANNUAL INDEXES, MICROFICHE, AND ONILINE DATABASES -- CALL

TOLLRREE 1-800-521-8110 (IN NY, AK, OR HI CALL COLLECT 1-212-463-6869).

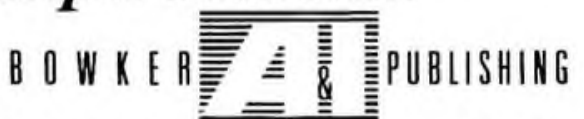

THE ABSTAACTING AND INDEXING DIVISION OF A. A. BOWKER

R.R. Bowker, 245 West 17 Street. New York, NY 10011 
subject is covered in geometry texts."

QX353-QC358 Light-“except for one 1984 book, section consists of older books from the ' 60 's. All the books are frequently checked out."

As I proceeded, I modified my methodology according to the subject area. In computer science, for example, I listed the specific languages and software programs taught at the college and used subject headings rather than call numbers to assess adequacy. In chemistry, use indicated that we needed to update the basic textbooks, but could forego purchasing advanced works in more specific areas.

From the assessment we learned that most of the collection had been purchased soon after the library opened in 1966, and little weeding and replacement had transpired since then. I wrote to the most prominent publishers of science books, acquired their catalogs, went through them and selected titles which would update the collection in specific topical areas. I also had an established file of titles selected from Choice, Library Journal, and Science Books and Films.

I sent the science program chairpersons copies of the assessment results and lists of possible new acquisitions. Response from the instructors was generally enthusiastic: they were pleased to note that a neglected area of the library had received intense scrutiny and were judicious in their selection of new book titles.

Once the initial assessment had been completed and purchasing had commenced I had to grapple with the problem of maintaining the collection according to the conclusions I had reached. We are not in the position of being able to turn our requirements over to a jobber and expecting this third party to match our profile to the material available. My approach was to update the assessment as new books came in; to review the assessment frequently to keep familiar with its results and our progress in addressing deficiencies; to note on the assessment when old books were removed; and, at the end of the year, to balance circulation figures for each subject area with purchases and book costs, so as to plan the next year's purchases.

This project was successful in evaluating one area of the library collection. Its application in the social sciences is doubtful, because of the inherent inter-disciplinary nature of many subjects. Business topics in our library are best updated by periodicals and standard reference tools. However, the English literature curriculum could be well served by a variation of this project, and this is the area targeted for assessment and development in the near future.

\section{ACRL publishing procedures}

\section{Developed by the ACRL Publications Committee, and accepted by the ACRL Executive Committee at their}

Spring meeting.

$\mathbf{P}$ ublications are a vital part of academic librarianship and the ACRL program. One of the purposes of ACRL is to promote and disseminate its members' and units' work in the fields of their expertise. The ACRL publications program is one major means of engaging in this promotion and dissemination. Publishing was identified as the num- ber one priority of ACRL members in a recent survey and ACRL units and members are generating ideas and projects that have publication potential in either a print or non-print format.

It is important that work completed by ACRL units be offered to ACRL for first publication consideration. Work of ACRL units may take the form 